\title{
Extinction is inevitable in the globalized world
}

\author{
Aishwarya Maheshwari ${ }^{1}$ \\ ${ }^{1}$ Banda University of Agriculture and Technology
}

July 23,2020

\begin{abstract}
No abstract - Extinction is a natural process and every species on this planet has an expiration date except Homo sapiens because we are extending our expiry at the cost of other species (Brook and Alroy 2017, Pimm et al. 2014, Ceballos et al. 2015). In contrast, biodiversity loss is not natural but a global issue and it is not caused by the globalization, but as a result of human activities at the global level (Pimm et al. 2014, Ceballos et al. 2015). Eventually, severe biodiversity losses lead to anthropogenic die-off and extinction of naturally occurring species (Pimm et al. 2014, Ceballos et al. 2015, DeVos et al. 2014). The previous, current and future extinction rates have been estimated using a variety of measures and their estimation methodologies vary (to be between 100 to 10,000 times higher than the natural extinction rate) but they clearly demonstrate that current extinction rates are far above than the "background" rates (Brook and Alroy 2017, Pimm et al. 2014, Ceballos et al. 2015, DeVos et al. 2014, Lamkin and Miller 2016). Aggravatedly, population declines and extirpations are appearing to be more graving than species extinction and negative cascading consequences on ecosystem services (Ceballosa et al. 2020). Substantial information is available on over-exploitation of natural resources by humans in the globalization perspective (Ceballosa et al. 2020, Millennium Ecosystem Assessment, 2005, Groom et al. 2006, Ehrnfeld 2003) and we have lost an estimated US\$ 4-20 trillion per year in ecosystem services owing to land-cover change and US\$ 6-11 trillion per year from land degradation during 1997 to 2011 (OECD 2019). Such loss also leads to an increased disease risk (Gilbert 2010) and recent coronavirus pandemic (COVID-19) might be one of the similar consequences.
\end{abstract}

\section{Letter}

Extinction is inevitable in the globalized world

Aishwarya Maheshwari

Department of Wildlife Sciences, College of Forestry, Banda University of Agriculture and Technology, Banda-210001, Uttar Pradesh, India (ORCID ID: 0000-0002-6338-4254)

Corresponding author: aishwaryamaheshwari@icloud.com

Extinction is a natural process and every species on this planet has an expiration date except Homo sapiens because we are extending our expiry at the cost of other species (Brook and Alroy 2017, Pimm et al. 2014, Ceballos et al. 2015). In contrast, biodiversity loss is not natural but a global issue and it is not caused by the globalization, but as a result of human activities at the global level (Pimm et al. 2014, Ceballos et al. 2015). Eventually, severe biodiversity losses lead to anthropogenic die-off and extinction of naturally occurring species (Pimm et al. 2014, Ceballos et al. 2015, DeVos et al. 2014). The previous, current and future extinction rates have been estimated using a variety of measures and their estimation methodologies vary (to be between 100 to 10,000 times higher than the natural extinction rate) but they clearly demonstrate that current extinction rates are far above than the "background" rates (Brook and Alroy 2017, Pimm et al. 2014, Ceballos et al. 2015, DeVos et al. 2014, Lamkin and Miller 2016). Aggravatedly, population declines and extirpations are appearing to be more graving than species extinction and negative cascading consequences on ecosystem services (Ceballosa et al. 2020). Substantial information is available on over-exploitation of 
natural resources by humans in the globalization perspective (Ceballosa et al. 2020, Millennium Ecosystem Assessment, 2005, Groom et al. 2006, Ehrnfeld 2003) and we have lost an estimated US\$ 4-20 trillion per year in ecosystem services owing to land-cover change and US\$ 6-11 trillion per year from land degradation during 1997 to 2011 (OECD 2019). Such loss also leads to an increased disease risk (Gilbert 2010) and recent coronavirus pandemic (COVID-19) might be one of the similar consequences.

Furthermore, such degraded ecosystems are either slow to recover or have lost their natural vigor to recover even after their exploitation stops (Moreno-Mateos et al. 2017). For example, global demand for food through agriculture expansion is one of the major causes of destruction and degradation of natural ecosystems and biodiversity loss and it restricts restoration of biodiversity on agricultural land (FAO 2010).

At present, climate change, biodiversity, environment and wildlife conservation are on the highest priority of several international treaties, conventions and national and international laws and legislations, however, the failures have been spectacular (Hoffmann et al. 2010). It is beyond doubt that we are facing sixth mass extinction in the Earth's 4.5 billion years of history (Ceballos et al. 2015, Ceballosa et al. 2020). In many cases, it has been purposeful and the global biodiversity suffers from similar threats globally such as pollution, climate change, unregulated and unsustainable harvesting of natural resources, the international trade of invasive species and diseases, habitat fragmentation, deforestation and urbanization. Unarguably, there is an ever-increasing demand of natural resources and their overexploitation in the past two centuries has accelerated the pace of extinction and now it appears unmanageable to alter "the Great Dying" in recent times.

Biodiversity is the major part of livelihoods that is susceptible to changes in globalization, especially the changes brought about by over exploitation of natural resources. An Indian civilization philosophy of "Vasudhaiva Kutumbakam" - the whole world is one family - may underpin the agenda of biodiversity conservation at the global level. Biodiversity conservation and globalization cannot remain isolated but need to become part of more integrated strategies for sustainable development that question hegemonic development paradigms.

\section{References:}

1. Brook BW, Alroy J. 2017. Pattern, process, inference and prediction in extinction biology. Biol. Lett. 13: 20160828. http://dx.doi.org/10.1098/rsbl.2016.0828

2. Ceballos G, Ehrlich PR, Barnosky AD, Garcia A, Pringle RM, Palmer TM. 2015. Accelerated modern human-induced species losses: Entering the sixth mass extinction. Science Advances 1: e1400253.

3. Ceballosa G, Ehrlichb PR, Dirzo R. 2020. Biological annihilation via the ongoing sixth mass extinction signaled by vertebrate population losses and declines. Proc Natl Acad Sci USA 117: 13596-13602.

4. DeVos JM, Joppa LN, Gittleman JL, Stephens PR, Pimm SL. 2014. Estimating the normal background rate of species extinction. Conservation Biology 29: 452-462

5. Ehrnfeld D. 2003. Globalisation: Effects on Biodiversity, Environment and Society. Conservation and Society, 1: 99-111.

6. Food and Agriculture Organization (FAO). 2010. Global Forest Resources Assessment 2010, http://www.fao.org/forestry/fra/fra2010/en/

7. Gilbert, N. 2010. More species means less disease. Nature https://doi.org/10.1038/news.2010.644

8. Groom MJ, Meffe GK, Carroll, CR. 2006. Principles of Conservation Biology, Sinauer Associates, Sunderland.

9. Hoffmann M, Hilton-Taylor C, Angulo A, Böhm M, Brooks TM, Butchart SH, Carpenter KE, et al. 2010. The Impact of conservation on the status of the world's vertebrates. Science 330: 1503-1509.

10. Lamkin M, Miller AI. 2016. On the challenge of comparing contemporary and deep-time biologicalextinction rates. BioScience 66: 785-789.

11. Millennium Ecosystem Assessment. 2005. Ecosystems and Human Well-being: Synthesis. Island Press, Washington, DC

12. Moreno-Mateos D, Barbier EB, Jones PC, Jones HP, Aronson J, López-López JA, McCrackin ML, Meli P, Montoya D, Benayas JMR. 2017. Anthropogenic ecosystem disturbance and the recovery debt. 
Nature Communications 8: 14163.

13. Pimm SL, Jenkins CN, Abell R, Brooks TM, Gittleman JL, Joppa LN, Raven PH, Roberts CM, Sexton JO. 2014. The biodiversity of species and their rates of extinction, distribution, and protection. Science 344: 1246752 .

14. The Organisation for Economic Co-operation and Development (OECD) 2019. Biodiversity: Finance and the Economic and Business Case for Action, report prepared for the G7 Environment Ministers' Meeting, 5-6 May 2019. 